\title{
Penerapan Algoritma K-Nearest Neighbors Pada Analisis Sentimen Metode Pembelajaran Dalam Jaringan (DARING) Di Universitas Kristen Wira Wacana Sumba
}

\author{
Andry A.P. Tanggu Mara ${ }^{1}$, Eko Sediyono ${ }^{2}$, Hindriyanto Purnomo ${ }^{3}$ \\ ${ }^{1}$ Program Studi Magister Sistem Informasi, Fakultas Teknologi Informasi, Universtas Kristen Satya Wacana \\ ${ }^{2}$ Dosen Program Studi Magister Sistem Informasi, Fakultas Teknologi Informasi, Universtas Kristen Satya Wacana \\ ${ }^{3}$ Dosen Program Studi Magister Sistem Informasi, Fakultas Teknologi Informasi, Universtas Kristen Satya Wacana \\ 1972019011@student.uksw.edu, 2eeko@uksw.edu*,3hindriyanto.purnomo@uksw.edu*
}

\begin{abstract}
Abstract-The education sector is one of the areas that has felt the major impact of the Covid-19 pandemic. The impact that arises is teaching and learning process must be carried out from home using the online learning method. This teaching and learning method raises a variety of responses from students. This is what makes researchers analyze these views, both in the form of positive opinions or negative opinions. The analysis process is carried out by applying sentiment analysis or opinion mining from the comment on Facebook, text mining is processed using the prepocessing method, labeled it to positive and negative. Based on the available data, a classification process is carried out using the K-Nearest Neighbors algorithm. Rapid Miner is used to experiment text data with the KNN algorithm in order to find the value of accuracy, precision and recall. From the results of research, it was obtained a value of $87.00 \%$ for accuracy and 0.916 for the AUC value. The values are high enough for the classification of student opinion against this pandemic so that this research is classified as Excellent Classification.
\end{abstract}

Keywords - Covid-19, Online Learning Model, K-Nearest Neighbors, RapidMiner

\begin{abstract}
Abstrak
Abstrak - Bidang pendidikan merupakan salah satu bidang yang merasakan dampak besar dari pandemi Covid-19. Dampak yang timbul adalah proses belajar mengajar harus dilakukan dari rumah dengan metode pembelajaran daring. Metode belajara mengajar ini menimbulkan respon atau pandangan yang beragam dari peserta didik. Hal ini yang membuat peneliti melakukan analisis terhadap pandangan-pandangan tersebut, baik yang berupa pendapat positif atau pendapat negatif. Proses Analisis dilakukan dengan menerapkan analisis sentimen atau opinion mining dari data komentar di media sosial Facebook, data teks diolah dengan metode prepocessing dan diberi label positif dan negatif. Berdasarkan data teks yang tersedia, dilakukan proses klasifikasi dengan algoritma K-Nearest Neighbors. RapidMiner digunakan untuk eksperimen data teks dengan algoritma KNN dengan tujuan mencari nilai akurasi, presisi dan recall. Dari hasil penelitian diperoleh nilai sebesar $87.00 \%$ untuk accuracy dan 0.916 untuk nilai AUC. Nilai-nilai yang cukup tinggi untuk klasifikasi opini mahasiswa terhadap pandemi ini sehingga penelitian ini digolongkan sebagai Excellent Classification.
\end{abstract}

Kata Kunci - Covid-19, Model Pembelajaran Daring, K-Nearest Neighbors, RapidMiner

\section{PENDAHULUAN}

Pandemi Virus Corona Disease 2019 ( Covid 19 ) membawa dampak yang sangat signifikan terhadap proses belajar mengajar disemua tingkatan pendidikan, tidak hanya di Indonesia tetapi di seluruh belahan dunia. Secara khusus di Indonesia sistem belajar mengajar dilakukan dari rumah, hal ini berdasarkan aturan dan anjuran pemerintah melalui Menteri Pendidikan dan Kebudayaan (Mendikbud) Indonesia untuk seluruh siswa belajar dari rumah (BDR) bahkan ujian nasional 2020 dibatalkan. Kebijakan belajar di rumah ini dilakukan untuk mengurangi interaksi fisik sebagai upaya pencegahan penularan virus corona jenis baru atau covid-19. Mendikbud berharap dengan diterapkannya pembelajaran daring atau jarak jauh ini siswa juga mendapatkan pengalaman baru dalam proses belajar [1].
Universitas Kristen Wira Wacana Sumba merupakan salah satu universitas yang terdampak wabah Covid 19 sehingga segala kegiatan mahasiswa "dirumahkan", belajar mengajar dari rumah menggunakan model pembelajaran dalam jaringan atau online. Terhitung sejak bulan Maret 2020 dimana anjuran pemerintah tentang Social Distancing selama masa pandemi Covid 19 dikeluarkan Unkriswina melalui Surat Edaran Rektor Nomor 019/EDR-R/2020 menerangkan bahwa perlu diperhatikan tindakan-tindakan untuk pencegahan penyebaran Covid 19 di lingkungan kampus sehingga perkuliahan dilakuakan dalam jaringan atau daring[2].

Sistem pendidikan dilakukan dengan metode dalam jaringan (online) dimana setiap aktifitas belajar dilakukan secara virtual melalui media-media yang tersaji di internet. Tentu ada dampak yang ditimbulkan, baik itu mendukung 
atau bahkan merugikan para peserta didik. Dampak positif yang diperoleh adalah aman dari wabah Covid 19, belajar lebih praktis dan fleksibel, hemat waktu dan tenaga, pendekatan belajar lebih personal, serta mudah didokumentasikan[3]. Namun disisi lain ada beberapa kendala yang muncul dalam penerapan pembelajaran daring. Pembelajaran melalui jaringan internet menjadi sulit dilakukan di beberapa daerah tertentu dengan jaringan yang tidak memadai mengingat Indonesia merupakan negara kepulauan yang pembangunan infrastruktur internatnya tidak merata (Hastini et al., 2020). Kuota internet tentu berbiaya sehingga bisa menjadi masalah bagi beberapa siswa yang mengalami kesulitan keuangan atau lemah ekonomi. Efektivitas dilakukannya pembelajaran daring juga bergantung pada kematangan dan kesiapan sekolah dalam hal ini guru pengajar. Tidak semua guru mampu menyampaikan keseluruhan materi dengan optimal melalui sistem pembelajaran [4].

Berdasarkan dampak-dampak yang ada maka fokus yang akan diteliti adalah mahasiswa dengan menggunakan metode Analisis Sentimen yang merupakan proses untuk mengetahui padangan atau opini seseorang terhadap peristiwa yang terjadi, baik itu berupa pandangan positif ataupun negatif. Opini dan pandangan mahasiswa dapat berupa tulisan ataupun lisan. K-Nearesr Neighbors merupakan algoritma yang digubakan untuk melakukan proses klasifikasi opini hasil analisis sentimen. Kelebihan dari algoritma K-Nearest Neighbor adalah terbukti dapat mencapai akurasi yang tinggi dan sesuai dengan perhitungan yang diterapkan dalam aplikasi-aplikasi[5]. Tujuannya adalah untuk mengklasifikasikan opini mahasiswa baik berupa opini positif maupun opini negatif dan akan dihitung nilai akurasi dengan pendekatan algoritma $K-N N$. Hasilnya dapat dijadikan bahan evaluasi terkait model pembelajaran daring selama masa pandemi.

\section{TINJAUAN PUSTAKA}

Penelitian terdahulu yang terkait klasifikasi terhadap analisis sentimen adalah klasifikasi artikel wikipedia oleh Hardiyanto dan Rahutomo (2016). Klasifikasi artikel Wikipedia Indonesia dimaksudkan untuk klasifikasi artikel di situs Wikipedia Indonesia dalam bentuk teks dengan memanfaatkan model text pre-processing dan diteruskan dengan pembobotan TF-IDF. Berdasarkan pembobotan tersebut, artikel-artikel dalam Wikipedia Indonesia itu diklasifikasikan dengan Algoritma K-Nearest Neighbor. Berdasarkan hasil pengujian manual menunjukkan akurasi kebenaran sebesar 60\%[6]. Perbandingan dengan penelitian ini adalah proses klasifikasi yang dilakukan dengan cara manual tanpa bantuan perangkat atau tools klasifikasi.

Penelitian Siti Ernawati dan Risa Wati pada tahun 2018, Penerapan algoritma K-Nearest Neighbors pada analisis sentimen review agen travel menunjukan beberapa hal sebagai berikut: pengolahan data dengan algoritma $K$ Nearest Neighbor (K-NN) yang menggunakan masingmasing 100 review positif dan negatif dengan 6 kata yang berkaitan dengan sentimen yaitu: Fast, Good, Great, Buruk, Cancel, dan Tunggu. Pembuktiannya adalah bahwa dengan menggunakan algoritma $K$-Nearest Neighbor $(K-N N)$, ia mencapai hasil akurasi terbaik dan berdasarkan perhitungan dalam aplikasi. Titik akurasi peninjauan agen perjalanan menggunakan K-Nearest Neighbor $(K-N N)$ algoritma mencapai nilai sebesar 87,00\% dan titik $A U C$ adalah 0,916 [7]. Ada beberapa hal yang menjadi kekurangan dari penelitian ini, yaitu algoritma KNN diterapkan secara teoritis sedangkan perumusan atau persamaan algoritma dalam mencari jarak atau kedekatan data sebagai proses klasifikasi tidak diterapkan.

Penelitian terkait pemanfaatan model pembelajaran dalam jaringan yang dilakukan oleh Toni Limbong (2020) menunjukan beberapa hal sebagai berikut: Universitas Katolik Santo Thomas Medan saat ini telah menetapkan dan melaksanakan belajar daring untuk mendukung program pemerintah dalam menghadapi wabah Covid-19 yang sedang terjadi. Hasil dari perhitungan menggunakan metode MAUT terhadap studi kasus efektivitas belajar daring menggunakan aplikasi Zoom dan Edmodo di Fakultas Ilmu Komputer Universtias Katolik Santo Thomas Medan menghasilkan pilihan yang lebih objektif dengan penilaian matakuliah Teori (0.88) sebagai penilaian tertinggi, disusul matakuliah Teori dan Praktikum (0.70), matakuliah Praktikum (0.42) dan matakuliah di Lapangan (0.20). Hasil perhitungan ini dapat dijadikan pendukung keputusan bahwa jika pimpinan akan membuat kebijakan ujian daring maka bentuk soal dan sifat ujian adalah bentuk Teori, boleh bersifat pilihan ganda, essay dan juga analisa[8]. Penelitian ini menggunakan pseudocode dan gabungan opini sehingga kesimpulan yang dihasilkan bersifat pandangan peneliti semata.

Beberapa hal mendasar yang akan digunakan dalam penelitian ini adalah penerapan analisis sentimen dan algoritma K-Nearest Neighbors sebagai metode untuk klasifikasi pandangan mahasiswa Unkriswina terhadap pemanfaatan pembelajaran dalam jaringan (daring) selama masa Lock Down oleh karena adanya wabah penyebaran Virus Corona. Penerapan pseudocode atau algoritma perhitungan jarak dan kedekatan sebagai bagian dari proses klasifikasi akan diterapkan.Tentu yang menjadi sasaran utama adalah bagaimana mengetahui pandangan mahasiswa selama mengikuti pembelajaran daring, yang tentunya pandangan mereka bervariasi sehingga perlu diklasifikasikan dan dipisahkan opini positif dan opini negatif.

\section{A. Analisis Sentimen}

Sentiment analysis atau opinion mining merupakan sebuah studi komputasi untuk mencari atau mengenali dan mengekspresikan opini, sentimen, evaluasi, sikap, emosi, subjektifitas, penilaian atau pandangan yang terdapat dalam suatu teks. Analisis sentimen dapat digunakan untuk mendapatkan persentase sentimen positif dan sentimen negatif terhadap seseorang, perusahaan, institusi, produk atau pada sebuah kondisi tertentu. Nilai dari analisis sentimen bisa dipecah menjadi 3 yakni, sentimen positif, sentimen negatif dan sentimen netral atau diperdalam lagi sehingga dapat menemukan siapa atau kelompok yang menjadi sumber sentimen positif atau sentimen negatif[9]. 
Langkah-langkah analisis sentimen klasifikasi terhadap data text-mining atau data teks adalah sebagai berikut:

1. Tahap awal: Mengumpulkan dataset seperti pendapat masyarakat, penilaian terhadap restoran atau produk dan lain-lain.

2 Pre-processing: tahapan yang mencakup Tokenization, Stopwords Removal, dan Stemming.

3. Transformation: Pembobotan dari data teks

4. Feature Selection: Tahap mengurangi data yang tidak diperlukan

5. Classification: Tahap klasifikasi teks yang biasanya menggunakan metode seperti: Naive Bayes, K-Nearest Neighbor, Support Vector Machine dan lain-lain.

6. Interpretation/Evaluation: Tahap evaluasi untuk menghitung nilai accuracy dan nilai Area Under the Curve[10].

\section{B. K-Nearest Neighbors}

Dalam buku Algoritma Data Mining, Kusrini menerangkan bahwa Algoritma K-Nearest Neighbors adalah pendekatan untuk mencari kasus dengan menghitung kedekatan antara kasus baru dengan kasus lama, yaitu berdasarkan pada pencocokan bobot dari sejumlah fitur yang ada[11]. Pada Pandangan yang lain disebutkan bahwa $K$ Nearest Neighbors adalah sebuah algoritma untuk melakukan klasifikasi pada objek berdasarkan data yang jaraknya paling dekat dengan objek tersebut. Data digambarkan ke dalam ruang berdimensi banyak, dimana masing-masing dimensi mencerminkan fitur dari data. Nilai $\mathrm{k}$ yang terbaik untuk algoritma ini bergantung pada data yang secara umum nilai k yang tinggi akan mengurangi efek noise pada klasifikasi, tetapi membuat batasan antara setiap klasifikasi menjadi lebih kabur[12]. Tujuan utama dari algoritma ini yaitu mengklasifikasikan suatu obyek berdasarkan atribut-atribut dan training sample. Algoritma K-Nearest Neighbor (K-NN) menggunakan klasifikasi kedekatan titik sebagai nilai perkiraan dari query instance yang baru. Berikut ini adalah cara untuk menentukan jarak kedekatan data dalam metode $K-N N[13]$ :

$$
d=\sqrt{\sum_{i=1}^{n}\left(a_{i}-b_{1}\right)^{2}}
$$

$$
\begin{aligned}
& \text { Keterangan: } \\
& \text { d }=\text { jarak } \\
& \text { a }=\text { data uji/testing } \\
& \text { b = sampel data } \\
& \text { i }=\text { variable data } \\
& \mathrm{n}=\text { Dimensi data }
\end{aligned}
$$

\section{Metode Penelitian}

Metode yang dilakukan adalah dengan melakukan pengamatan pada form diskusi dan komentar di grup Facebook yang kemudian dijadikan dataset untuk diolah sebagai subjek penelitian. Adapun tahapan penelitian sebagai berikut:

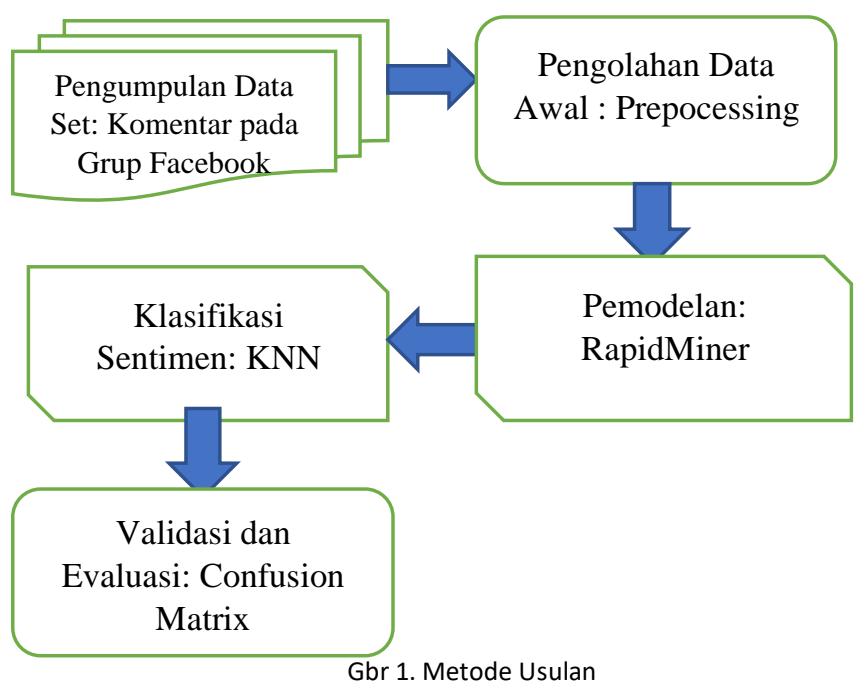

\section{A. Pengumpulan Data Set}

Tahap pertama yang dilakukan adalah pengumpulan data dengan cara membuat akun grup Facebook beranggotakan mahasiswa aktif Unkriswina dan memberikan ruang untuk menjawab pertanyaan yang berkaitan dengan pembelajaran daring di tengah pandemi Covid 19. Data yang dimaksud adalah opini atau pandangan dari mahasiswa Universitas Kristen Wira Wacana Sumba sebagai sasaran penelitian. Data yang diperoleh dari kumpulan opini tersebut diintegrasikan kedalam dataset.

\section{B. Pengolahan Data Awal}

Setelah pengumpulan data langkah selanjutnya adalah pengolahan data, peneliti mengambil sampel sebanyak 200 data training. Pada pengolahan awal data melalui preprocessing sebagai berikut:

\section{1) Case Folding}

Case Folding adalah proses mengubah semua huruf data teks menjadi huruf kecil.

\section{2) Tokenization}

Tokenization adalah mengumpulkan semua kata dan menghilangkan tanda baca maupun simbol yang bukan huruf, seperti “, . . ; ) dan lain-lain.

\section{3) Stopword Removal}

Kemudian selanjutnya yaitu proses memeriksa stopword list, stopword list adalah daftar kata-katapenghubung antar kalimat yang dihilangkan. Tetapi jika tidak terdapat kata penghubung maka proses akan dilanjutkan tanpa menghilangkan kata pada dokumen tersebut. 


\section{4) Stemming}

Stemming merupakan salah satu proses dari mengubah token yang berimbuhan menjadi kata dasar, dengan menghilangkan semua imbuhan yang ada pada token tersebut. Pentingnya stemming dalam proses pembuatan sistem adalah untuk menghilangkan imbuhan pada awalan dan akhiran[14].

\section{Pemodelan}

Pada penelitian ini proses eksperimen menggunakan RapidMiner 8.2. Data training yang digunakan adalah opini mahasiswa Unkriswina Sumba melalui Media Sosial Facebook yang dikelompokkan menjadi 2 yaitu opini positif dan opini negatif.

\section{Klasifikasi Sentimen}

Pada penelitian ini, metode klasifikasi yang diterapkan adalah K-Nearest Neighbors yang terbukti mencapai hasil akurasi yang baik dan sesuai dengan perhitungan yang diterapkan dalam sebuah aplikasi. Adapun rumus untuk melakukan perhitungan kedekatan antara dua kasus dapat dilihat pada persamaan 2 sebagai berikut:

Similarity $(\mathrm{T}, \mathrm{S})=\frac{\sum_{i=1}^{n} f(T, S) * w}{\mathrm{w}}$

Keterangan:

T : Kasus Baru

S : Kasus Terdahulu

n : Jumlah Atribut Dalam Setiap Kasus

i : Atribut Individu 1 s.d n

f : Fungsi Similarity Atribut I antara T dan S

w : Bobot Yang Diberikan Pada Atribut ke-i

Kedekatan biasanya berada pada nilai antara 0 s.d. 1 , nilai 0 artinya kedua kasus mutlak tidak mirip, sedangkan nilai 1 kasus mirip dengan mutlak[11].

\section{E. Validasi dan Evaluasi}

Tahap validasi dilakukan dengan menerapkan 10 foldcross validation. Proses validasi memiliki dua sub-proses yaitu: training set dan testing set. Sub-proses training data digunakan untuk melatih model algoritma yang sudah ditentukan pada tahap pemodelan dengan data pelatihan yang ada. Setelah model algoritma dilatih pada tahap subproses training, berikutnya akan dilakukan testing. Adapun Evaluasi atau pengujian hasil klasifikasi $K-N N$ menggunakan Confussion Matrix yang merupakan alat yang dapat digunakan untuk melakukan analisis terhadap seberapa baik klasifikasi yang telah dihasilkan dan dapat mengenali tuple dari kelas yang berbeda.

TABEL 1. CONFUSSION MATRIX[15].

\section{Prediksi}

Positi Negati

\begin{tabular}{cccc}
\cline { 3 - 4 } & & $\mathrm{f}$ & $\mathrm{f}$ \\
\hline \multirow{3}{*}{ Aktual } & Positif & TP & FN \\
& Negatif & FP & TN \\
\hline
\end{tabular}

1. True Positive (TP): data dari klasifikasi yang memiliki label positif dan label klasifikasi tersebut sesuai dengan nilai aktual.

2. True Negative (TN): data dari klasifikasi yang memiliki label negatif dan label klasifikasi tersebut sesuai dengan nilai aktual.

3. False Positive (FP): data dari klasifikasi yang memiliki label positif dan label tidak sesuai dengan nilai aktual.

4. False Negative (FN): data dari klasifikasi yang memiliki label negatif dan label tidak sesuai dengan nilai aktual.

\section{HASIL DAN PEMBAHASAN}

Data diperoleh dari komentar-komentar dalam form diskusi grup

Facebook: https://www.Facebook.com/groups/465615134612746 dengan jumlah responden lebih dari 200 dan data komentar sebanyak 291. Data tersebut kemudian diberikan label positif dan negatif sehingga menghasilkan data komentar sebanyak 200 komentar, data berlabel ini yang dijadikan dataset penelitian. Dalam mengolah data dengan tujuan untuk memperoleh model yang sesuai dengan kebutuhan penelitian, maka digunakanlah sebuah tools Rapidminer versi 8.2. Hal ini dikarenakan penelitian ini termasuk ke dalam model text-mining.

\section{A. Koleksi Dokumen Opini}

Dokumen Opini yang digunakan merupakan hasil dari mengumpulkan opini mahasiswa Unkriswina, sebanyak 200 dokumen opini yang terdiri dari 26 opini positif dan 174 opini negatif. 200 data opini positif negatif ini dijadikan dokumen training serta ada 50 dokumen testing.

TABEL 2. DOKUMEN OPINI

\begin{tabular}{|l|l|l|l|}
\hline No. & $\begin{array}{l}\text { Opini } \\
\text { Mahasiswa }\end{array}$ & $\begin{array}{l}\text { Opini } \\
\text { Training }\end{array}$ & $\begin{array}{l}\text { Opini } \\
\text { Testing }\end{array}$ \\
\hline 1 & Positif & 25 & - \\
\hline 2 & Negatif & 175 & - \\
\hline 3 & Total & 200 & 50 \\
\hline
\end{tabular}

Dokumen Opini pada tabel 1 akan diolah dengan pendekatan Prepoccessing dan penerapan klasifikasi opini dengan mendahulukan tahap normalisasi data.

TABEL 3. DOKUMEN OPINI SEBELUM PREPOCCESSING

\begin{tabular}{|l|l|}
\hline No. & Dokumen Opini \\
\hline 1 & $\begin{array}{l}\text { Kuliah dari rumah bisa sambil bermain dengan } \\
\text { teman-teman }\end{array}$ \\
\hline 2 & $\begin{array}{l}\text { Belajar Online Sama Sekali Tidak Bagus, Saya } \\
\text { lebih banyak tidak paham }\end{array}$ \\
\hline 3 & Pada DASARNYA kalau model belajar Online \\
\hline
\end{tabular}




\begin{tabular}{|l|l|}
\hline & $\begin{array}{l}\text { ini diterapkan dengan sungguh-sungguh oleh } \\
\text { DOSEN dan kami MAHASISWA... saya rasa } \\
\text { semua akan baik adanya (-) dan kami pun } \\
\text { dapatkan ILMU dengan EFEKTIF!!! }\end{array}$ \\
\hline 4 & $\begin{array}{l}\text { Kuliah Online sangat merepotkan, banyak } \\
\text { keluar biaya untuk beli paket, sudah begitu } \\
\text { jaringan tidak stabil di sini }\end{array}$ \\
\hline 5 & $\begin{array}{l}\text { Saya tidak punya Hp apalagi Laptop, Kuliah } \\
\text { Online buat saya harus cari uang lebih lagi } \\
\text { untuk beli hp }\end{array}$ \\
\hline 6 & $\begin{array}{l}\text { Lebih bnyak kami dituntut belajar sendiri } \\
\text { sebenarnya }\end{array}$ \\
\hline 7 & $\begin{array}{l}\text { Kuliahnya ok tapi saya tidak kenal dosennya } \\
\text { dan juga teman2 di kelas, hanya bisa lihat } \\
\text { mereka punya foto saja }\end{array}$ \\
\hline 8 & $\begin{array}{l}\text { Kuliah online tapi kalo tidak ada internet sama } \\
\text { dengan bohong, susah. }\end{array}$ \\
\hline 9 & $\begin{array}{l}\text { Dosen mengajar kebanyakan tidak jelas, tiba2 } \\
\text { kasih tugas. Materi sedikit yang diajar tugas } \\
\text { segudang yang dikasih }\end{array}$ \\
\hline 10 & $\begin{array}{l}\text { Saya kurang konsentrasi kalau kuliah online, } \\
\text { belum lagi kalau jaringan sudah gangguan, } \\
\text { parah sudah }\end{array}$ \\
\hline
\end{tabular}

Tabel 3 merupakan dokumen-dokumen opini tahap awal pada data training yang belum dilakukan prepoccessing. Berikut ini merupakan tahapan prepoccessing dengan pendekatan case folding, tokenizing, stopword removal pada dokumen opini di tabel 3:

\section{B. Pre-Pocessing Data Komentar}

Sebelum dataset diklasifikasikan dengan metode $K$-Nearest Neighbors, sebagai tahap awal akan dilakukan prepocessing sebagai berikut:

TABEL 4. PREPOCESSING OPINI MAHASISWA

\begin{tabular}{|l|l|}
\hline No. & Opini Mahasiswa \\
\hline 1 & kuliah dari rumah sambil main dengan teman \\
\hline 2 & belajar online tidak bagus saya tidak paham \\
\hline 3 & $\begin{array}{l}\text { dasar model belajar online terap dengan sungguh } \\
\text { oleh dosen dan mahasiswa semua akan baik dan } \\
\text { dapat ilmu efektif }\end{array}$ \\
\hline 4 & $\begin{array}{l}\text { kuliah online repot keluar biaya beli paket } \\
\text { jaringan tidak stabil }\end{array}$ \\
\hline 5 & $\begin{array}{l}\text { saya tidak punya hp laptop harus cari uang beli } \\
\text { hp }\end{array}$ \\
\hline 6 & $\begin{array}{l}\text { kami tuntut belajar sendiri } \\
\text { mereka ok tidak kenal dosen teman lihat foto }\end{array}$ \\
\hline 7 & $\begin{array}{l}\text { kuliah online tidak ada internet sama bohong } \\
\text { sosen ajar tidak jelas tiba kasih tugas materi }\end{array}$ \\
\hline 9 & $\begin{array}{l}\text { kurang konsentrasi kuliah online jaringan } \\
\text { gangguan parah }\end{array}$ \\
\hline 10
\end{tabular}

Selanjutnya adalah penentuan term frekuensi pada data training hasil dari pendekatan prepocessing, seperti yang ditunjukan pada tabel 5 di bawah ini:

TABEL 5. TERM FREKUENSI DATA TRAINING

\begin{tabular}{|l|l|l|l|}
\hline No. & Term & Id_dokumen & Jumlah \\
\hline 1 & kuliah & 1 & 2 \\
\hline 2 & dari & 1 & 1 \\
\hline 3 & rumah & 1 & 1 \\
\hline 4 & sambil & 1 & 1 \\
\hline 5 & main & 1 & 1 \\
\hline 6 & teman & 1 & 1 \\
\hline 7 & belajar & 2 & 1 \\
\hline 8 & online & 2 & 2 \\
\hline 9 & tidak & 2 & 2 \\
\hline 10 & bagus & 2 & 1 \\
\hline 11 & tidak & 2 & 2 \\
\hline 12 & paham & 2 & 1 \\
\hline 13 & kuliah & 4 & 2 \\
\hline 14 & online & 4 & 2 \\
\hline 15 & repot & 4 & 1 \\
\hline 16 & keluar & 4 & 1 \\
\hline 17 & biaya & 4 & 1 \\
\hline 18 & banyak & 4 & 1 \\
\hline 19 & beli & 4 & 1 \\
\hline 20 & paket & 4 & 1 \\
\hline
\end{tabular}

Hasil dari term frekuensi data training berupa token kata yang selanjutnya dilakukan tahapan klasifikasi, akan tetapi lebih dahulu dilakukan pelabelan kelas pada setiap opini dengan tujuan tools yang digunakan dapat mengenali dokumen kelas dari opini mahasiswa.

TABel 6. Pelabelan Data Training

\begin{tabular}{|c|c|c|}
\hline No. & Opini Mahasiswa & Kelas Sentimen \\
\hline 1 & $\begin{array}{l}\text { kuliah dari rumah sambil } \\
\text { main dengan teman }\end{array}$ & Positif \\
\hline 2 & $\begin{array}{l}\text { belajar online tidak bagus } \\
\text { saya tidak paham }\end{array}$ & Negatif \\
\hline 3 & $\begin{array}{l}\text { dasar model belajar online } \\
\text { terap dengan sungguh } \\
\text { oleh dosen dan mahasiswa } \\
\text { semua akan baik dan } \\
\text { dapat ilmu efektif }\end{array}$ & Positif \\
\hline 4 & $\begin{array}{l}\text { kuliah online repot keluar } \\
\text { biaya beli paket jaringan } \\
\text { tidak stabil }\end{array}$ & Negatif \\
\hline 5 & $\begin{array}{l}\text { saya tidak punya hp laptop } \\
\text { harus cari uang beli hp }\end{array}$ & Negatif \\
\hline 6 & kami tuntut belajar sendiri & Negatif \\
\hline 7 & $\begin{array}{l}\text { kuliah ok tidak kenal } \\
\text { dosen teman lihat foto } \\
\text { mereka }\end{array}$ & Negatif \\
\hline 8 & $\begin{array}{l}\text { kuliah online tidak ada } \\
\text { internet sama bohong }\end{array}$ & Negatif \\
\hline 9 & $\begin{array}{l}\text { dosen ajar tidak jelas tiba } \\
\text { kasih tugas materi sedikit } \\
\text { ajar tugas gudang }\end{array}$ & Negatif \\
\hline 10 & $\begin{array}{l}\text { kurang konsentrasi kuliah } \\
\text { online jaringan gangguan } \\
\text { parah }\end{array}$ & Negatif \\
\hline
\end{tabular}

Tabel 6 adalah tahap labelisasi data training opini

Andry A.P. Tanggu Mara : Penerapan Algoritma K-Nearest Neighbors... 
mahasiswa yang selanjutnya akan diuji dengan algoritma $K$ Nearest Neighbors.

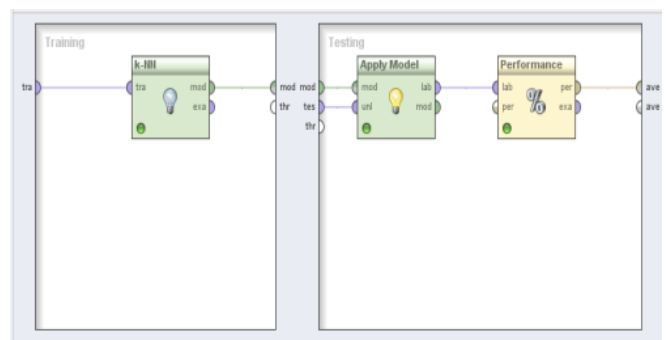

\section{Klasifikasi Dengan Metode K-Nearest Neighbors}

Sebelum dilakukan klasifikasi, terlebih dahulu dilakukan perhitungan kedekatan jarak memanfaatkan persamaan yang ada, yaitu:

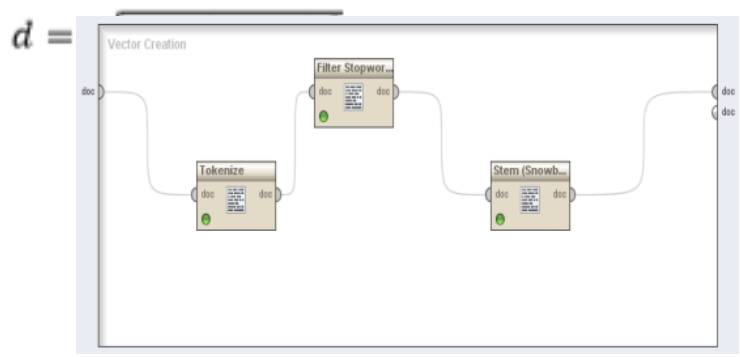

Perbandingannya adalah pada data sample dan data uji. Data sample yang digunakan contohnya id_document = 1 dengan data uji id_document $=\mathrm{x}$. Maka penerapan rumusnya adalah sebagai berikut:

$$
\begin{aligned}
d_{1} & =\sqrt{\sum_{i=1}^{p}(1)^{2}+(-0,07175)^{2}+(0,5)^{2}+(-0,25)^{2}+(1)^{2}+(0,22222222)^{2}+(1)^{2}} \\
d_{1} & =\sqrt{\sum_{i=1}^{p} 1+0,00514806+0,25+0,0625+1+0,04938271+1} \\
d_{1} & =\sqrt{\sum_{i=1}^{p} 3,36703077} \\
d_{1} & =1.83494708
\end{aligned}
$$

TABEL 7. DATA JARAK ANTARA DATA UjI

\begin{tabular}{|l|l|l|}
\hline Data Uji & Data Sample & Jarak \\
\hline \multirow{5}{*}{ Id_document = x } & Id_document = 1 & 1.83494708 \\
\cline { 2 - 3 } & Id_document = 2 & 1.45308990 \\
\cline { 2 - 3 } & Id_document = 3 & 1.17634227 \\
\cline { 2 - 3 } & Id_document $=4$ & 0.08900544 \\
\cline { 2 - 3 } & Id_document $=5$ & 1.07443387 \\
\cline { 2 - 3 } & Id_document = 6 & 0.45009112 \\
\cline { 2 - 3 } & Id_document = 7 & 1.09231099 \\
\cline { 2 - 3 } & Id_document = 8 & 1.52096677 \\
\cline { 2 - 3 } & Id_document = 9 & 1.69230019 \\
\cline { 2 - 3 } & Id_document = & 0.03670674 \\
& 10 & \\
\hline
\end{tabular}

Jarak pada data uji seperti pada tabel 7 dapat diurutkan menjadi terdekat seperti berikut ini:

TABEL 8. HASIL HITUNGAN JARAK TERDEKAT

Gbr 2. Input Validasi 1

\begin{tabular}{|l|l|l|}
\hline Data Uji & Data Sample & Jarak \\
\hline \multirow{5}{*}{ Id_document = x } & Id_document $=$ & 0.03670674 \\
& 10 & \\
\cline { 2 - 3 } & Id_document $=6$ & 0.45009112 \\
\cline { 2 - 3 } & Id_document $=4$ & 0.08900544 \\
\cline { 2 - 3 } & Id_document $=5$ & 1.07443387 \\
\cline { 2 - 3 } & Id_document $=7$ & 1.09231099 \\
\cline { 2 - 3 } & Id_document $=3$ & 1.17634227 \\
\cline { 2 - 3 } & Id_document $=2$ & 1.45308990 \\
\cline { 2 - 3 } & Id_document $=8$ & 1.52096677 \\
\cline { 2 - 3 } & Id_document $=9$ & 1.69230019 \\
\cline { 2 - 3 } & Id_document $=1$ & 1.83494708 \\
\hline
\end{tabular}

Berikut ini merupakan tahapan pemrosesan data menggunakan tools RapidMiner dari hasil pre-poccessing pada tahap awal:

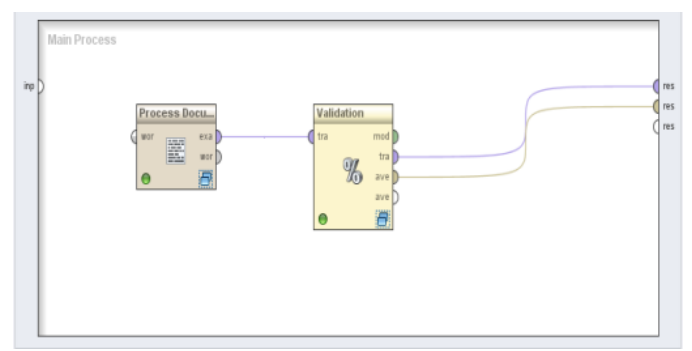

Gbr 4. Penerapan K-Nearest Neighbors

Gbr.3 Tahap Pre-poccessing

TABEL 9. Evaluasi DOKUMEN TRAINING DENGAN KNN

\begin{tabular}{c|cccc} 
NO & $\begin{array}{c}\text { KELAS } \\
\text { SENTIM } \\
\text { EN }\end{array}$ & $\begin{array}{c}\text { BOBOT } \\
\text { AKURA } \\
\text { SI }\end{array}$ & $\begin{array}{c}\text { PRECIS } \\
\text { SION }\end{array}$ & $\begin{array}{c}\text { REC } \\
\text { ALL }\end{array}$ \\
\hline $\mathbf{1}$ & Positif & $\begin{array}{c}26 \\
\mid\end{array}$ & 1.0 & $\mathbf{1 . 0}$ \\
\hline \multirow{2}{*}{2} & & $13 \%$ & & \\
& Negatif & 174 & 1.0 & $\mathbf{1 . 0}$ \\
& $\begin{array}{c}\text { TOTAL/ } \\
\text { AVERA }\end{array}$ & $\begin{array}{c}87 \% \\
\text { GE100\% }\end{array}$ & $\mathbf{1 . 0}$ & $\mathbf{1 . 0}$ \\
& & & & \\
\hline
\end{tabular}

Tabel 9 merupakan hasil dari proses training sentimen $K$ Nearest Neighbors dengan nilai akurasi pada sentimen positif sebesar $13 \%$ dan akurasi pada sentimen negatif yang sangat besar mencapai $87 \%$ dari total akurasi $100 \%$. Sedangakan hasil precission pada kelas sentimen positif bernilai 1 dan kelas sentimen negatif bernilai 1, dengan demikian hasil precission sangat akurat. Sedangkan untuk hasil recall sama dengan hasil precission dengan hasil kelas sentimen positif dan negatif bernilai 1. Artinya hasil sentimen data training bernilai benar semua klasifikasi sentimennya. 
D. Perubahan Nilai k

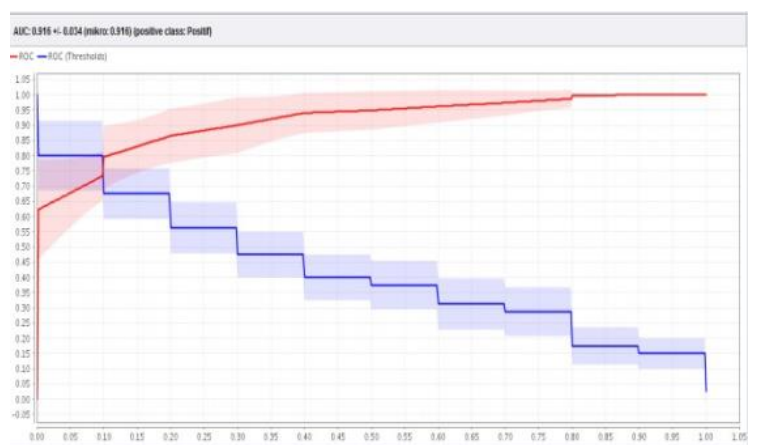

Berikut ini merupakan proses eksperimen dengan merubah nilai $\mathrm{k}$ untuk menentukan nilai akurasi, presisi, recall, serta nilai $A U C$ :

\begin{tabular}{|c|c|c|c|c|}
\hline \multicolumn{5}{|c|}{ TABEL 10. EKSPERIMEN PERUBAHAN NILAI K } \\
\hline $\begin{array}{c}\text { Nilai } \\
\text { K }\end{array}$ & $\begin{array}{c}\text { Accura } \\
\text { cy }\end{array}$ & $\begin{array}{c}\text { Precisi } \\
\text { on }\end{array}$ & $\begin{array}{c}\text { Reca } \\
\boldsymbol{l l}\end{array}$ & AUC \\
\hline $\mathbf{1}$ & 80.00 & 77.88 & 84.00 & $\mathbf{0 . 5 0 0}$ \\
\hline $\mathbf{2}$ & 82.50 & 89.82 & 74.00 & $\mathbf{0 . 8 2 3}$ \\
\hline $\mathbf{3}$ & 80.50 & 78.48 & 85.00 & $\mathbf{0 . 8 7 4}$ \\
\hline $\mathbf{4}$ & 82.00 & 84.37 & 79.00 & $\mathbf{0 . 8 9 4}$ \\
\hline $\mathbf{5}$ & 81.50 & 79.77 & 85.00 & $\mathbf{0 . 9 0 7}$ \\
\hline $\mathbf{6}$ & 83.50 & 88.39 & 78.00 & $\mathbf{0 . 9 0 8}$ \\
\hline $\mathbf{7}$ & 84.00 & 85.54 & 83.00 & $\mathbf{0 . 9 1 0}$ \\
\hline $\mathbf{8}$ & $\mathbf{8 7 . 0 0}$ & $\mathbf{9 2 . 9 4}$ & 81.00 & $\mathbf{0 . 9 1 6}$ \\
\hline $\mathbf{9}$ & 85.00 & 86.05 & 84.00 & $\mathbf{0 . 9 3 6}$ \\
\hline $\mathbf{1 0}$ & 84.50 & 87.72 & 81.00 & $\mathbf{0 . 9 0 9}$ \\
\hline $\mathbf{1 1}$ & 86.50 & 87.16 & 86.00 & $\mathbf{0 . 9 1 2}$ \\
\hline $\mathbf{1 2}$ & 85.50 & 89.51 & 81.00 & $\mathbf{0 . 9 1 4}$ \\
\hline $\mathbf{1 3}$ & 86.00 & 87.71 & 84.00 & $\mathbf{0 . 9 1 2}$ \\
\hline $\mathbf{1 4}$ & 85.00 & 89.98 & 79.00 & $\mathbf{0 . 9 1 1}$ \\
\hline $\mathbf{1 5}$ & $\mathbf{8 3 . 5 0}$ & $\mathbf{8 5 . 0 8}$ & $\mathbf{8 1 . 0 0}$ & $\mathbf{0 . 9 1 2}$ \\
\hline & & & & \\
\hline
\end{tabular}

Berdasarkan pada tabel 10 yaitu perubahan nilai $\mathrm{k}$, maka hasil accuracy tertinggi ada pada nilai $\mathrm{k}=8$ dengan nilai sebesar $\underline{87.00 \%}$ dan nilai AUC $\underline{0.916}$.

\section{E. Validasi dan Evaluasi}

Berdasarkan tabel 10 yaitu Accuracy dengan metode KNN menghasilkan nilai class recall Negatif sebesar $93.00 \%$ dan Positif sebesar $81 \%$, nilai class Precision Negatif sebesar 83.04\% dan Positif sebesar 92.05\%.

Accuracy dengan metode $K N N$ pada tabel 10 diturunkan kedalam Confusion Matrix. Hasilnya adalah sebagai berikut:

$$
\begin{aligned}
& \text { Accuracy }=\frac{(T N+T P)}{(T N+F N+T P+F P)} \\
& \text { Accuracy }=\frac{(93+81)}{(93+7+81+19)} \\
& \text { Accuracy }=\frac{174}{200}=0.87=87.00 \%
\end{aligned}
$$

Berdasarkan nilai akurasi tersebut dapat dibuatkan grafik AUC seperti dibawah ini:

\section{Gbr 5. KNN Pada Grafik AUC}

Gambar 5 yaitu tampilan grafik $A U C$ dengan penerapan metode $K$-Nearest Neighbors dihasilkan nilai Area Under Curve $(A U C)=0.916$. Sehingga dari nilai-nilai yang telah diperoleh, disimpulkan bahwa klasifikasi keakuratan dalam penelitian ini termasuk kedalam Excellent Classification yang dapat dilihat pada panduan keakuratan nilai AUC seperti di bawah ini:

$$
\begin{aligned}
\text { 1. } & 0.90-1.00 & =\text { Excellent Classification; } \\
\text { 2. } & 0.80-0.90 & =\text { Good Classification } \\
\text { 3. } & 0.70-0.80 & =\text { Fair Classification } ; \\
\text { 4. } & 0.60-0.70 & =\text { Poor Classification } \\
\text { 5. } & 0.50-0.60 & =\text { Failure }[16] .
\end{aligned}
$$

\section{5) Kesimpulan}

Penelitian telah dilakukan dengan menerapkan klasifikasi data komentar dari media sosial Facebook dengan memperhatikan pandangan mahasiswa Universitas Kristen Wira Wacana Sumba terhadap pemanfaatan model pembelajaran dalam jaringan atau online selama masa pandemi Covid-19 dengan memanfaatkan metode K-Nearest Neighbors. Data 26 review positif dan 174 review negatif digunakan sebagai dataset untuk kemudian diklasifikasikan dengan hasil nilai akurasi sebesar $87.00 \%$ dan nilai $A U C$ sebesar 0.916 sehingga hasil ini dijadikan acuan penggolongan kelompok klasifikasi yaitu Excellent Classification. Berdasarkan hasil penelitian diperoleh nilai akurasi yang sangat baik dan memperoleh nilai AUC yang cukup besar.

Dalam kaitannya dengan proses pembelajaran daring, nilai yang dihasilkan berupa presentasi opini negatif sebesar $87.00 \%$ menunjukan bahwa sebagian besar populasi mahasiswa menilai pembelajaran daring yang selama ini diterapkan tidak efektif. Presentasi opini negatif tersebut didukung dengan nilai akurasi berdasarkan algoritma K-Nearest Neighbors sebesar $87 \%$ yang artinya presentasi tersebut sangat tinggi nilai keabsahannya. Sehingga dapat ditarik kesimpulan akhir bahwa perlu ada evaluasi terhadap model pembelajaran daring di Unkriswina Sumba, baik itu kompetensi dosen 
dalam mengajar secara daring, penanganan jaringan internet yang tidak merata bagi mahasiswa, solusi bagi mahasiswa yang secara ekonomi terbatas dan tidak mampu belajar secara daring.

\section{Referensi}

[1] Asmara, C. G. (2020, March 25). Para Siswa, Simak Surat Terbaru Mendikbud Nadiem Untuk Kalian. CNBC Indonesia. Retrieved from https://www.cnbcindonesia.com/tech/2020032512 4101-37-147405/para-siswa-simak-surat-terbarumendikbud-nadiem-untuk-kalian

[2] https://unkriswina.ac.id/informasi-kampusunkriswina/surat-edara-rektor-tentang-covid19. Diakses 31 Agustus 2020

[3] Pakpahan, R., \& Fitriani, Y. (2020). Analisa Pemanfaatan Teknologi Informasi Dalam Pembelajaran Jarak Jauh di Tengah Pandemi Virus Corona Covid-19. JISAMAR: Journal of Information System, Applied, Management, Accounting and Research, 4(2), 30-36.

[4] Morgan, H. (2020). Best Practices for Implementing Remote Learning during a Pandemic. The Clearing House: A Journal of Educational Strategies, Issues and Ideas, 93(3), 134-140.

[5] Sani, R. R., Zeniarza, J., \& Luthfiarta, A. (2016). Pengembangan Aplikasi Penentuan Tema Tugas Akhir Berdasarkan Data Abstrak Menggunakan Algoritma K- Nearest Neighbor. Prosiding seminar Nasional Multi Disiplin Ilmu \& Call For Papers, 103111.

[6] Hardiyanto. E., Rahutomo. F., 2016, Studi Awal Klasifikasi Artikel Wikipedia Bahasa Indonesia Dengan Menggunakan Metoda K Nearest Neighbor. Prosiding Sentrinov (Seminar Nasional Terapan Riset Inovatif), [S.1.], v. 2, n. 1, p. 158-165, 2477-2097.

[7] Ernawati. S., Wati. R., 2018, Penerapan Algoritma KNearest Neighbors Pada Analisis Sentimen Review Agen Travel, Jurnal Khatulistiwa Informatika: Vol. VI No. 1 Juni 2018 2339-1928.

[8] Limbong T., Simarmata J., 2020, "Menentukan Matakuliah yang Efektif Belajar Daring (Belajar dan Ujian) dengan Metode Multi-Attribute Utility Theory (MAUT)", Jurnal Rekayasa Sistem dan Teknologi Informasi (RESTI): Vol. 4 No. 2 (2020) 370-376.

[9] Liu B., 2015, Sentiment Analysis: Mining Opinions, Sentiments, and Emotions, University of Illinois at Chicago: Cambridge University Press.
[10] Fatyanosa, T. N., \& Bachtiar, F. A., 2017. Classification method comparison on Indonesian social media sentiment analysis. In: IEEE, 2017 International Conference on Sustainable Information Engineering and Technology (SIET). Malang, Indonesia 24-25 November 2017. Indonesia

[11] Kusrini, L., T., Emha, 2009, Algoritma Data Mining, Penerbit Andi, Yogyakarta.

[12] Romadloni, N.T., Santoso, I., Budilaksono, S., 2019, Perbandingan Metode Naïve Bayes, KNN dan Decision Tree Terhadap Analisis Sentimen Transportasi KRL Commuter Line, IKRA-ITH Informatika: Vol. III No. 2.

[13] Lidya, K.,S, Opim, S., \& Syahril, E. (2015). Sentiment Analysis Pada Text Bahasa Indonesia Menggunakan Support Vector Machine (SVM) dan K-Nearest Neighbor (K-NN). Seminar Nasional Teknologi Informasi dan Komunikasi 2015, Yogyakarta.

[14] K., Sigit, dkk., 2019, Perbandingan Metode Klasifikasi Analisis Tokoh Sentimen Pada Komentar Media Online, RESTI: Jurnal Rekayasa Sistem dan Teknologi Informasi Vol.3 No. 2 (2019) 176-183.

[15] Han, J., Kamber, M., \& Pei, J. (2012). Data Mining Concepts \& Techniques. Morgan Kaufmann.

[16] Gorunescu, Florin (2011). Data Mining: Concepts, Models, and Techniques. Verlag Berlin Heidelberg: Springer. 